\title{
Lapita and Western Pacific Settlement: Progress, prospects and persistent problems
}

\author{
Stuart Bedford ${ }^{1}$ and Christophe Sand ${ }^{2}$ \\ ${ }^{1}$ Department of Archaeology and Natural History \\ Research School of Pacific and Asian Studies \\ The Australian National University \\ Canberra, Australia \\ stuart.bedford@anu.edu.au \\ 2 Department of Archaeology of New Caledonia \\ Nouméa \\ New Caledonia \\ christophe.sand@gouv.nc
}

\section{Introduction}

Lapita pottery and its associated antiquity and significance first began to be revealed in stratigraphically controlled archaeological excavations some 55 years ago (Gifford and Shutler 1956). Since that time it has remained a central focus for Pacific archaeologists (Clark et al. 2001; Kirch 1997; Sand 2003; Spriggs 1990a) and has subsequently led to the definition of a cultural complex that is associated with an archaeological horizon that can be identified from Island New Guinea to Samoa (Golson 1971:75). Reading through earlier general summary articles (Golson 1971; Green 1979; Kirch 1988) one is struck by both the increased progress but also the continuing complications in the understanding of the Lapita phenomenon. The papers published in this volume reflect on a broad range of interrelated themes including Lapita origins, chronology, patterns of settlement, migration, interaction and exchange, sampling strategies and ceramic analyses; all of which relate to aspects highlighting both advances and impediments associated with Lapita research.

\section{Lapita origins}

The question of Lapita origins has been debated for decades (see Pawley this volume). As increasing archaeological research results began to emerge from both the Pacific and Island Southeast Asia in the 1970s it was argued that the presence of this intricately decorated ceramic tradition was related primarily to Neolithic Austronesian expansion into the region (Bellwood 1978; Shutler and Marck 1975; Shutler and Shutler 1975). 
From the beginning of the 1980s a strongly indigenist counter scenario took shape, which advocated that Lapita was equally likely to have been an essentially localised development centred in the Bismarck region and was certainly much more complex than a simple migratory event from the West (Allen 1984; White and Allen 1980; White et al. 1988). The multi-institution Lapita Homeland Project was specifically designed to test the different hypotheses, but generally failed to achieve a consensus (Allen and Gosden 1991; Gosden et al. 1989). The debate on the origins of Lapita culminated or at least has largely remained at a standstill since Green's compromise Triple I model of intrusion, innovation and integration (Green 1991). In this short discussion we do not intend to examine in detail the arguments relating to indigenous verses migratory positions, rather we reflect on the nature of ceramic remains and how they might inform us in relation to the wider debate (see also Sand this volume).

Most current views in relation to Lapita tend to coalesce on the subject of the origins of the Lapita ceramic design system and certainly on the location of where that development occurred. The finely decorated Lapita ceramics are generally seen these days as something that developed mainly in the Bismarck Archipelago, following the introduction of the art of pottery making from Southeast Asia (Green 1985; Kirch 1997). Explanations for this, however, have largely been restricted to the idea that the dentate along with the design system may have been a medium used on other surfaces (like tattooing) and that in the Bismarcks it was simply transferred to the ceramics (Green 1985; Kirch 1997:142-143; Torrence and White 2001).

One of the major lines of evidence cited (albeit often with an associated caveat) as supporting its development in the Bismarcks is lack of any similar dentate-stamped ceramics having been identified further to the west. But how confident can we be that this is in fact the actual situation? Although a small number of specifically targeted projects searching for antecedent Lapita sites in the grand expanse of coastal and island West Papua and Southeast Asia have been undertaken (see Spriggs 2007 for the latest summary), the often very large islands of this vast region render the search for first ceramic settlement sites much more difficult than much of the Western Pacific. It must be also added that the majority of excavations that have been carried out in Island Southeast Asia to date have been undertaken in cave and rockshelter sites. If this same strategy had been the primary focus of excavations in the Pacific over the last 50 years of Lapita research, we would have little more than a handful of sherds and sites across the entire Lapita spectrum.

The only site found in the Western Pacific where there has been arguments relating to actual evidence for Lapita antecedents is Mussau. Kirch originally argued that the plainware of Area A at site ECA of Talepakemalai represented "later, 'simplified' Lapitoid ceramics in the first millennium B.C." (Kirch 1987: 172), before later asserting that the concentrations of plainware and decorated sherds found in different parts of the site represented different but contemporaneous activity areas (Kirch 1997:172). He has more recently argued that the plainware ceramics are earlier, have parallels with contemporary plainwares in Southeast Asia and that the dentate-stamping at the site developed later (Kirch 2001:205). While more details regarding the Mussau site assemblage are eagerly awaited, we argue that this scenario along with the idea of simple transference of a design system found on one medium to pottery seems unlikely. The very fact of the "fullblown" nature of the Far Western Lapita ceramics recovered from the earliest sites in the Bismarcks (which are relatively dispersed and chronologically indistinguishable) suggests otherwise to us. At these sites, the earliest thus far identified phase of Lapita ceramics, the pottery is at its most spectacular, with needlepoint dentate, a specific range of vessel forms and often very complex design motifs. There is no hint at any of these sites, or at least none that have been mentioned, that indicate an experimental or developmental phase in the earliest Lapita decoration. These earliest pots and their often elaborate and finely applied decoration required high levels of skill and therefore suggest some degree of familiarity at least with the techniques employed.

Pre-Lapita age dentate-stamped sherds have more recently been reported from northern Luzon (Tsang 2007), indicating the presence of this comb-tool type and its use in the decoration of ceramics prior to its appearance in the Bismarcks. At the same time, however, the tools used in northern Luzon sites appear 
thus far to have been only straight with no evidence for any use of curved dentate tools. When this decorative technique is employed in the Bismarcks we may possibly be witnessing some level of innovation both in tools and design, although this has yet to be determined. In-depth analysis of the actual combed tools used to make the dentate-stamped Lapita motifs suggests that they were probably made out of turtle scute (Ambrose 1999, and this volume) and for the first time the bent or curved form, which has been demonstrated as being integral in the production of the Lapita motifs, makes its appearance. These data we believe demonstrate that it was unlikely to have been a straight forward transfer of tattooing technique (Kirch 1997:142), but that rather a more complex process was involved (see Sand this volume). Certainly in relation to the emergence of Far Western Lapita, we do not currently have enough accumulated data to fully disentangle and determine the levels of influence that might be ascribed specifically to an intrusive and sudden migratory event or to local innovation.

Whatever the scenario relating to Southeast Asian influences, emerging data associated with pre-Lapita era populations of the Bismarcks are highlighting the essential need to integrate aspects such as the evidence for complex exchange networks and the production of specialized items associated with this period, into the wider debate (Torrence 2007). Other possible regional influences also need to be taken into account including natural events such as the massive $\mathrm{W}-\mathrm{K} 2$ volcanic eruption in New Britain in reshaping social constrains around 3350 BP, just at the time of the first widespread appearance of Lapita (Specht 2007). A more inclusive debate is also likely to lead to a more balanced picture that avoids the spurious implications or interpretations of supposed greater or lesser levels of social evolution in a particular population, a concern long ago expressed by Golson (1977). The Lapita phenomenon was likely to have involved a myriad of complex contact and interaction situations over the centuries, with varying and changing outcomes depending on the place and the time period, as is the case with all migratory events that arrive on the shores of already occupied beaches.

\section{Lapita boundaries}

The number and temporal boundaries of Lapita sites have radically changed since being first tentatively advanced in the 1970s (Golson 1971). While the geographical boundaries or limits of where Lapita pottery has been discovered (Manus to New Caledonia to Samoa) remain fairly much the same (Anderson et al. 2001), the number of recorded Lapita sites has expanded at an exponential rate including in those archipelagos where Lapita was once seen as marginal or non-existent. In 1979 the tally was around 50 sites (Green 1979), up to 79 in 1988 (Kirch and Hunt 1988:9), 182 by the year 2000 (Anderson et al. 2001) and now in 2007 some 229 (see Table 1). They comprise a wide range of site types and activity areas (Burley, Specht, Specht and Torrence this volume) that span an accumulated overall period of around 7-800 years from Northwest to the East. While certainly many sites have only been sampled at the most basic level, the pattern now emerging does point to the widespread nature of the Lapita horizon. In archipelagos where the archaeology has been undertaken in collaboration with geomorphological research or assessment the Lapita "gaps" have either been infilled through the identification of early ceramic sites (e.g. Burley, Connaughton, Felgate this volume) or post-depositional processes have been identified which explain why Lapita sites might be extremely difficult to locate (Dickinson 2006; Felgate 2001; Green 2002a). The more recent discoveries in Fiji (Nunn this volume; Nunn et al. 2007) also highlight that even in regions where there has already been a number of archaeological research programs focusing on the Lapita period it is difficult to confidently state that there will be no further major sites found. The benefits and requirement of long-term research programs committed to specific regions are also being highlighted by the results gleaned over many decades from a number of archipelagos (New Britain [Specht and Torrence this volume; Summerhayes 2000], Solomon Islands [Felgate 2001; this volume], the Reef/Santa Cruz [Chiu this volume; Green 1976], Vanuatu [Bedford et al. this volume; Galipaud and Swete-Kelly this 
volume], New Caledonia [Sand 2000; this volume] and Tonga [Burley this volume; Burley et al. 2002]). We argue that the accumulating evidence is severely weakening arguments postulating "leap-frogging" (Felgate this volume) during initial expansion, a long speculated scenario for some regions of the Lapita distribution and again more recently argued for the central Solomons (Sheppard and Walter 2006). At the same time, our often simple, single directional arrow indicating Lapita expansion into Remote Oceania, being undertaken by one homogeneous cultural group during one narrow time-event, is most likely overshadowing multiple departures of diverse groups in various directions over a couple of centuries, who did not all stop in the same places along their journey (Sand 2007).

Sites like Bourewa (Nunn this volume) or the Teouma Lapita cemetery (Bedford et al. 2006), recently discovered on islands with some history of archaeological interest at least, are unlikely to be the last of such discoveries. In fact if current rates of Lapita site discovery in Fiji and Vanuatu continue, then we might expect to easily double the current numbers of sites in these archipelagos. Concomitantly, the previously proposed Lapita preference for small islands appears to be increasingly less supported at least for Remote Oceania, although questions of chronology remain to be integrated into the model. After the numerous examples from Mainland New Caledonia (Sand 2006), a new case in point is Vanuatu, where Lapita sites have now been found at Erueti and Teouma on Efate, the third largest island in the group $\left(915 \mathrm{~km}^{2}\right)$ and at Matantas, Big Bay, northern Santo, the largest island $\left(3900 \mathrm{~km}^{2}\right)$ (Bedford and Spriggs 2007). It may well have been a quite different scenario in Near Oceania where pre-Lapita populations had long been in residence. But the postLapita landscape transformations over the last millennia on mountainous islands that are sometimes tens of thousands of square kilometres in area, also renders the finding of the earliest ceramic settlement sites a major challenge (Specht and Torrence this volume). Certainly, particularly in volcanically active regions, surface surveys and excavations in caves and rockshelters alone are not enough to determine Lapita presence. Major post-depositional landscape change and island size are also still likely to be major influencing factors in the current known western boundaries of Lapita, almost certainly on mainland New Guinea but also further west (Kirch 1988:158; Spriggs 1984, 2007). Finally, while Lapita sites remain overwhelmingly coastal there are a growing number of sites that have now been identified some distance from the sea (Anderson et al. 2001; Specht and Torrence this volume).

\section{Provinces and chronology}

Through the pioneering stylistic analyses of Lapita ceramics along with a limited number of radiocarbon dates, researchers were able to establish that there was a broad clinal west-east pattern of Lapita settlement with accompanying "distance decay" in ceramic decoration. On evidence available in the mid 1970s, Western and Eastern Lapita styles were initially proposed (Green 1978, 1979) with a Far Western being added some years later (Anson 1983). Over time as more and more sites have been excavated across the Lapita spectrum a series of interlinked stylistic "Provinces" have been proposed, namely Far Western (Bismarck Archipelago [cf. Kirch 1997]), Central (Reef/Santa Cruz and north and central Vanuatu [Sand 2001]), Southern (southern Vanuatu and New Caledonia [Sand 2000]) and Eastern (Fiji, Tonga, Samoa [Burley et al. 1999; Kirch 1997]).

Summerhayes $(2000,2001)$ however, has argued that the primary factor in Lapita ceramic variation is chronological and suggested that more appropriate terms for the different phases of the changing Lapita design system should be Early, Middle and Late Lapita. He quite rightly pointed out that geographically-loaded terms such as Western and Eastern can be seen as misleading. He argued in fact, that the data available indicates there was no geographical divide and interaction was sustained, as evidenced for example in the similarities of the late Lapita ceramics from Tonga and the Bismarcks (Summerhayes 2000:235). Best (2002) has argued otherwise, suggesting that perceived similarities have more to do with the simplicity of widespread designs 
which are seen in the later part of the sequence rather than anything to do with levels of interaction. More recently the proposal of simple temporal divisions has been further questioned, following focused research in relation to gauging chronological variation in Lapita ceramics. Results show that vessel form, decorative finesse, and design structure and content are not always a definitive marker of chronological divergence or levels of interaction (Bedford et al. this volume; Clark and Murray 2006; Chiu 2005:27; Sand 2001:70; Sand et al. 1998:41).

Far Western or Early Lapita remains geographically restricted to the Bismarck Archipelago as identified some time ago (Anson 1983), with the possible exception of recent evidence from northern Vanuatu (Galipaud and Swete-Kelly this volume; Galipaud pers. comm. 2006). In this northern Melanesian region it has been argued that there was a Lapita "pause" before rapid expansion further east into Remote Oceania (Kirch 1997). This "pause" argument is of course linked to the idea that dentate-stamping was a development that occurred in the Bismarcks and so a time period of some kind is required for this to have happened. Specht (this volume) reviews the time period for this "pause" by reassessing radiocarbon dates for the earliest sites in Near and Remote Oceania and shortens previous estimates of the "pause" to 150-250 years. The emerging overall similarities found amongst the Lapita ceramics in the Reef/Santa Cruz, Vanuatu and New Caledonia as well as the earliest sites in Fiji (Nunn this volume; Nunn et al. 2004) and Tongatapu (Burley and Dickinson 2001; Burley pers. comm. 2007), appear to support a scenario of a shorter "pause" before a first phase of very rapid expansion out of Near Oceania. This same scenario is also supported by the linguistic evidence (Pawley this volume).

Whether the primary drivers of ceramic stylistic change across the Lapita spectrum are temporal, geographical, cultural (Best 2002; Clark and Murray 2006; Sand 2001; Summerhayes 2000) or as seems the most likely, a varying combination of all these factors (Green 2003; Sand 2007), it remains an unresolved and on-going debate in Lapita research and one which will remain so until regional Lapita ceramic sequences are further refined and published in detail. One of the few archipelagos which is beginning to produce a more detailed regional Lapita sequence is New Caledonia (Sand 2006). The sequence demonstrates the emergence of some distinctive vessel forms and motif combinations during the 250 years of the local chronology (Sand this volume).

Immediately post-dentate stamped ceramic sequences in different areas are also beginning to shed some light on the regional diversification debate. There is emerging evidence from some archipelagos in Remote Oceania of dentate-stamping dropping out by $2800 \mathrm{BP}$ (e.g. central and southern Vanuatu and New Caledonia) and distinctive regionally diverse ceramic sequences developing (Bedford 2006a; Bedford and Clark 2001; Sand 1999). However, while this is happening dentate-stamping continues a little later in northern Vanuatu (Bedford 2003) and remains present in places like Tonga (Burley 1998) for another one to two centuries, indicating at the very least that there was substantial regional variation and suggesting that at least both geographical and temporal factors have influenced the Lapita design system (Green 2003). As with all things Lapita, we must be wary of assuming that data sets (which can be often outdated or incomplete) restricted to a particular region are representative of the entire Lapita Cultural Complex over space and time (Green and Kirch 1997). Aside from a few possible exceptions (Anson et al. 2005; Torrence and Stevenson 2000), we do, however, see it as very unlikely that Lapita dentate-stamping continues anywhere in the Western Pacific beyond c. 2500 BP.

\section{Persistent problems}

Lapita archaeology has generally, until relatively recently, been necessarily in a pioneering research mode, establishing boundaries and chronology, settlement patterns, basic artefactual sequences, and the profiling of Lapita ceramic decoration and form. Large-scale areal excavations that would make possible at least partial 
investigation of villages or even single house sites have been generally lacking and as a consequence there has been limited potential for modelling and discussion of Lapita social dynamics based on archaeological evidence (Green 2002b).

Another major factor that has impaired progress on these topics is the poor state of preservation of many of the Lapita sites excavated to date. As Green noted decades ago "the integrity of deposits in Lapita sites represents a major and continuing problem" (Green 1979:31). The vast majority of the more than 200 Lapita sites that have been recorded to date are generally poorly preserved, as the stratigraphy is often shallow and has been heavily mixed and saturated by tropical rainfall over millennia. Most Lapita sites have been identified through surface survey where collections of sherds and other remains are exposed on the ground surface, indicating post-depositional turbation. The only very recent identification of the potentially widespread nature of painted Lapita is a reflection of this situation (Bedford 2006b). We argue there needs to be a greater assessment of taphonomic process associated with Lapita sites. If patterns of settlement and subsistence are being summarised from the recovered remains they must be assessed against such variables as the site's state of preservation and the percentage of the site that has been sampled (see Sheppard and Green this volume). While an assessment of or comment on the levels of mixing or disturbance at a site is often made, this is rarely translated into the summary conclusions relating to a particular site and the supposed patterns identified from the record (see also Spriggs 1999:17-18).

Another major flaw in Lapita research is the lack of analysis and publication of the Lapita sites that have been excavated (noted amongst others by Clark and Murray 2006; Green 1979; Kirch 1988; Spriggs 1990b; Summerhayes 2001). Often when attempting such a basic exercise as comparing sherds from a number of sites one is forced to revisit the original excavated collections which are inevitably housed in many different institutions.

Chronology has long been a central research aspect in Lapita studies and the results have been used to model such aspects as Lapita migration and cultural and social changes over time. Radiocarbon dating and ceramic seriation have featured prominently although the former tends to hold a somewhat undeserving pre-eminence when conclusions regarding sites are presented. The attraction of "hard science" in the form of radiocarbon dating has long ensnared Pacific archaeologists' but the associated vagaries, of which we have become increasingly aware (see Kirch and Hunt 1988; Spriggs 1990b, 1996; Spriggs and Anderson 1993), have also provided much confusion and uncritical conclusions. There has in the past been a tendency for archaeologists interpretations to be overwhelmingly influenced by radiocarbon dates rather than assessing those dates in relation to the recovered archaeological data. Now long gone are the once widely accepted claims of Lapita appearing soon after $4000 \mathrm{BP}$, with a succeeding 1500 years or more of a dentate-stamping pottery tradition, to be replaced today by first appearance at around 3400-3300 BP and being present as a decorative technique for 500 to 600 years in Near Oceania and anywhere from 50 to over 400 years in Remote Oceania, depending on individual islands.

However, even though the problems with radiocarbon dating have now long been identified, if we undertake the exercise of compiling radiocarbon dates from a whole number of Lapita sites, especially in Remote Oceania, we repeatedly find that those chosen to date the earliest and latest phases of a Lapita occupation within and across archipelagos will overlap within two standard deviations because of the flatness of the calibration curve around 3000 BP (Anderson and Clark 1999; Pearson 1993: Fig 1b). The flat section of the calibration curve around $2500 \mathrm{BP}$ is also a major obstacle in assessing ceramic change around this crucial period of transition from Lapita to later traditions. Sites that may appear from the archaeological remains to represent a short-lived occupation will return a two sigma date of 2700-2300 BP. Other dating variables which continue to confuse the picture are variability in Delta $\mathrm{R}$ values for marine shells of the region (Jones et al. 2007), as well as the potential problem of in-built age in unidentified charcoal samples (Kirch and Hunt 1988; Spriggs 1990b) and even in long-lived shell species (Fiona Petchey pers. comm. 2007). 


\section{Prospects}

With the rapidly accumulating dataset associated with Lapita sites across the Western Pacific, we are beginning to fully realise the complex nature of Lapita and the major challenges in gleaning a deeper understanding from the archaeological record. Increasing awareness of this complexity alone is a major advance and has stimulated a series of critical reassessments (exemplified in a number of papers in this volume) of theories relating to Lapita that were developed decades ago on much sparser evidence than we have at hand today.

Future excavation and sampling strategies need to be modified. Although invariably easier said than done the employment of areal excavations at targeted sites must be a major priority. We might then move beyond collecting and sifting through small samples of very large midden areas and the thus far recorded two house sites for the entire Lapita region (Kirch 1997:171; Sheppard and Green 1991) and into greater intra-site detail which in turn may provide archaeological insights into Lapita social organisation.

As already mentioned the detailed analysis, illustration and publication of excavated sites is essential if we want to go beyond our present-day basic comparative studies. There are many excavated Lapita collections that have languished in boxes for decades or have only reached the preliminary publication stage. A first effort should be a digital record of these collections (which is some cases have deteriorated since excavation) that can ultimately be accessed on the web, as is already the case for part of the Reef/Santa Cruz data (http:/ / magic. lbr.auckland.ac.nz/anthpd/content/archive/).

There needs to be much more fieldwork particularly in those regions which appear to currently represent Lapita gaps or boundaries (West Papua, Central Solomons, Vanua Levu). In particular, further intensive surveys and excavations need to target open coastal sites on a series of islands west of the Bismarcks, with programs taking into account tectonic variability and coastal progradation over the past 4000 years. This remains a major research priority and may provide us with a basic understanding of the cultural specificity of this region during the advent of Lapita (Sand, Liu and Chiu 2007). Recent publications associated with this very research objective show for example the existence of now securely dated pre-Lapita age dentate-stamped pottery in Luzon (see Tsang 2007), a result that has major implications for our discussions relating to the origins of the Lapita design system and the decoration technique in northern Island Melanesia. In parallel with efforts further west, the Bismarcks themselves still require major research input. Although the Lapita Homeland Project achieved a number of important results, it is still the case that the overall Lapita chronology of the Bismarcks remains unclear: when does Lapita first appear, is it already fully-blown or are we still missing an earlier step, what are the regional diversification processes like and when do the dentate-stamped decorations finally drop out etc? All these questions pertain directly to our understanding of the Lapita dynamics in the rest of the Western Pacific, which need to be reassessed in tandem with renewed investigations. Without clear answers from the Bismarcks as well as further West, no definitive reconstruction of the first settlement of Remote Oceania can be conclusively proposed.

Finally, it needs to be stressed that some programs should focus on a number of already excavated key Lapita sites which require re-investigation. These are sites which have attracted often heated academic debate over the years, although in some cases it has been an exercise in scrapping over scraps. This sort of initiative appears to be underway at Watom, the earliest Lapita site recorded almost 100 years ago, which has seen a number of contested interpretations. The most recent substantial publication has concluded that the most profitable area of the site in terms of preserved deposits has yet to be excavated (Anson et al. 2005) and which may inspire a further archaeological expedition to the site (Richard Walter pers. comm. 2007). 


\section{Updated inventory}

As part of the overall preparation of this volume, we have compiled an inventory of sites where dentatestamped pottery has been found since the comprehensive list of Anderson et al. (2001). We follow the historical pattern of such inventories (Clark et al. 2001; Green 1979; Kirch and Hunt 1988) in that we include sites where a dentate-stamped component of decoration is included in the ceramics recovered. This will no doubt attract the now familiar charge of being "dentate-centric" but dentate decoration is both a chronological and symbolically significant marker. We are well aware that the Lapita ceramic series includes decorative techniques such as appliqué, incision, excising and shell impressing along with an often substantial component of plain pots, but we concur with Summerhayes (2000), amongst many others (e.g., Kirch 1990:128), who notes that where the "fundamental nature of interaction does change is with the end of Lapita. This regionalisation is seen in part with the disappearance of dentate vessels. If dentate vessels were social markers, then their change over time and their disappearance reflects a greater social breakdown" (Summerhayes 2000:235). Dentate decorated vessels were an integral social and cultural component of the populations linked with one of the major Pacific migratory colonising events (Green 2003). Moreover, all non-dentate forms of decorative technique and the plainware vessels are also found after the dentate phase. Additionally, by focusing on the relatively shortlived dentate-stamped phase of Pacific prehistory we are concentrating on fundamental research issues and processes associated with prehistoric migration, interaction and colonisation which have both regional and global significance (Anderson et al. 2001:3).

Since the year 2000 there have been eight new sites found in Island New Guinea (six in New Britain; two in New Ireland); two in the Western Province of the Solomons; 14 in Vanuatu; three in New Caledonia; 13 in Fiji and five in Tonga. Jim Specht confirmed the number of newly identified sites from New Britain but also pointed out some modifications required of the 2001 inventory. Sites that were found prior to 2001 but not included in the inventory (Tuam Island, Aitape, Ali Island and Vunailiu, Watom) are included in Table 1 above. Three sites should also be removed (due to an absence of dentate-stamping) from the 2001 inventory, Talasea area FEB, Garua Island FRD, Kandrian area (Apugi Island). As in the case of previous tallies of Lapita sites, reporting of new sites from different archipelagos almost always relates to the levels of research being undertaken in a particular region. The Table follows the format of Anderson et al. (2001) and includes national site register codes if available, site name, a general description of locality, site extent, contents, the ceramic series in terms of the localised sequence, age in calendrical years BP (gleaned from relevant radiocarbon dates or design motifs) and key references. We expect that an inventory such as this is bound to include a small number of inaccuracies and we ask that our colleagues simply bear with us.

\begin{tabular}{|c|c|c|c|c|c|c|c|}
\hline CODE & $\begin{array}{l}\text { LOCATION/ } \\
\text { NAME }\end{array}$ & LOCALITY TYPE & $\begin{array}{r}\text { EXIENT } \\
\text { (sqm) }\end{array}$ & CONTENTS & $\begin{array}{c}\text { CERAMIC } \\
\text { SERIES }\end{array}$ & AGE & REFERENCE \\
\hline \multicolumn{8}{|c|}{ Mainland New Guinea } \\
\hline \multicolumn{8}{|l|}{ Soudaun Province } \\
\hline No code & Aitape & unknown & - & surface sherd & ?Late & - & Swadling et ol. 1988 \\
\hline No code & Tubungbale, Ali Island & coastal flat & - & surface sherd & ?Late & - & Terrell and Welsch 1997 \\
\hline \multicolumn{8}{|l|}{ West New Britain } \\
\hline \multicolumn{8}{|l|}{ Morobe Province } \\
\hline KLK & Tuam Island, Siassi & coastal flat & 2000 & pottery & Middle to Late & $3150-2750$ & Lilley 2002 \\
\hline \multicolumn{8}{|c|}{ Willoumez Peninsula isthmus } \\
\hline FACU & & hill on divide & - & surface pottery & - & - & Specht and Torrence this volume \\
\hline FACZ & Mt Krummel & inland foothill & - & surface pottery & - & - & Specht and Torrence this volume \\
\hline FACR & Whiteman Range & inland foothill & - & surface pottery & Late & 2800 & Specht and Torrence this volume \\
\hline
\end{tabular}




\begin{tabular}{|c|c|c|c|c|c|c|c|}
\hline \multicolumn{8}{|l|}{ Tolaseo } \\
\hline $\mathrm{FCT}$ & Lagenda Island & beach/intertidal & - & surface pottery & - & - & Specht and Torrence in press \\
\hline \multicolumn{8}{|l|}{ Garua Island } \\
\hline FYS & & beach/intertidal & - & pottery & - & $3350-3100$ & Specht and Torrence in press \\
\hline FAAL & & beach/intertidal & - & surface pottery & - & - & Specht and Torrence in press \\
\hline \multicolumn{8}{|c|}{ East New Britain } \\
\hline \multicolumn{8}{|l|}{ Wotom } \\
\hline SAU & Vunailau & coastal hill/cliff & - & surface pottery & - & - & Specht 1968 \\
\hline \multicolumn{8}{|l|}{ New Ireland } \\
\hline \multicolumn{8}{|l|}{ Emira Island } \\
\hline No code & Егагае & coastal flat & - & full range & Early & - & Summerhayes et al. 2007 \\
\hline \multicolumn{8}{|l|}{ Tonga Island } \\
\hline ETM & Angkitkita & coastal flat & - & pottery and lithics & Late & 2750 & Garling 2003 \\
\hline \multicolumn{8}{|l|}{ Solomons } \\
\hline \multicolumn{8}{|l|}{ New Georgio } \\
\hline No code & Loloma & intertidal & 17500 & pottery and lithics & Late & - & Felgate this volume \\
\hline \multicolumn{8}{|c|}{ Kolombangaro } \\
\hline No code & Poitete & intertidal & - & surface sherds & Late & - & Summerhayes and Scales 2005 \\
\hline \multicolumn{8}{|c|}{ New Caledonia } \\
\hline \multicolumn{8}{|c|}{ West coast } \\
\hline v8 & Vavouto & coastal flat & 10000 & full range & Early to Late & $2900-2750$ & Sand 2006 \\
\hline GD 2006-042 & Gouaro & coastal flat & no estimate & pottery & ?late & - & Вагр 2006 \\
\hline \multicolumn{8}{|l|}{ Eost coost } \\
\hline No code & Kouəoua & coastal flat & no estimate & pottery & ?late & - & Sand 2006 \\
\hline \multicolumn{8}{|l|}{ Vanuatu } \\
\hline \multicolumn{8}{|c|}{ Moto Lovo, Banks Islands } \\
\hline No code & Nerenugman & back beach & 3000 & full range & Middle to Late & - & Bedford and Spriggs pers. comm. \\
\hline \multicolumn{8}{|l|}{ Sonto } \\
\hline No code & Big Bay/Matantas & back beach & 3500 & pottery and lithics & Late & $2900-2800$ & Bedford and Spriggs 2007 \\
\hline \multicolumn{8}{|l|}{ Aore } \\
\hline No code & Makué & back beach & - & full range & Early to Late & $3150-2950$ & Galipaud and Swete-Kelly this volume \\
\hline No code & west coast & back beach & - & surface pottery & - & - & Galipaud 2001 \\
\hline No code & SDA Mission & back beach & - & surface pottery & - & - & Galipaud 2001 \\
\hline \multicolumn{8}{|l|}{ Tutubo } \\
\hline No code & east coast & back beach & - & surface pottery & - & - & Galipaud 2001 \\
\hline No code & southeast coast & back beach & - & surface pottery & - & - & Galipaud 2001 \\
\hline \multicolumn{8}{|l|}{ Moveo } \\
\hline No code & northeast coast & coastal flat & - & pottery & - & - & Galipaud and Vienne 2005 \\
\hline No code & east coast & coastal flat & - & pottery & - & - & Galipaud and Vienne 2005 \\
\hline Molokula & & & & & & & \\
\hline No code & Uripiv Island & back beach & 2000 & full range & Late & $2800-2600$ & $\begin{array}{l}\text { Bedford 2003; Horrocks and Bedford } \\
2005\end{array}$ \\
\hline No code & Wala Island & back beach & 1000 & full range & Late & $2800-2600$ & Bedford 2003 \\
\hline No code & Atchin Island & back beach & 2000 & full range & Late & $2800-2600$ & Bedford 2003 \\
\hline No code & Vao Island & back beach & 3000 & full range & Early to Late & $3000-2600$ & Bedford 2003, 2006b \\
\hline Efote & & & & & & & \\
\hline No code & Teouma & $\begin{array}{l}\text { back beach/ } \\
\text { promontory }\end{array}$ & 2000 & full range & Early to Late & $3100-2800$ & Bedford et al. 2004, 2006 \\
\hline Fiji Islands & & & & & & & \\
\hline Viti Levu and & & & & & & & \\
\hline No code & Bourewa & sandspit/beach & 12500 & full range & Early to Late & $3000-2700$ & Nunn et al. 2004; Nunn this volume \\
\hline No code & Rove Beach & coastal flat & - & pottery & Late & - & Kumar et al. 2004 \\
\hline No code & Waikereira Bay & coastal flat & - & surface sherds & Late & - & Nunn this volume \\
\hline No code & Jugendars Farm Bay & coastal flat & - & surface sherds & Late & - & Nunn this volume \\
\hline
\end{tabular}




\begin{tabular}{|c|c|c|c|c|c|c|c|}
\hline No code & Tomato Patch Bay & coastal flat & - & surface sherds & Late & - & Nunn this volume \\
\hline No code & Qoqo Island & tombolo & 5000 & full range & Late & $2850-2650$ & Nunn et al. 2006 \\
\hline No code & \multicolumn{2}{|c|}{ Naitabale, Moturiki Island back beach } & 300 & full range & Early to Late & $3000-2700$ & Nunn et al. 2007 \\
\hline No code & Navutulevu & coastal flat & - & surface sherd & - & - & Kumar et al. 2004 \\
\hline No code & Taviya, Ovalau Island & coastal flat & - & surface sherd & - & - & Nunn et al. 2004 \\
\hline No code & Qaqaruku, NE Viti Levu & rockshelter & - & surface sherd & Late & - & Kumar 2002 \\
\hline \multicolumn{8}{|l|}{ Yaduo } \\
\hline No code & Vagariki & coastal flat & - & pottery & Late & 2600 & Nunn et al. 2005 \\
\hline \multicolumn{8}{|c|}{ Lou Group } \\
\hline \multicolumn{8}{|c|}{ Noyou Island } \\
\hline No code & Na Masimasi & coastal dune & - & full range & Late & - & 0'Day et al. 2004 \\
\hline No code & Vulago & coastal dune & 5000 & full range & Late & - & O'Day et al. 2004 \\
\hline \multicolumn{8}{|l|}{ Tonga } \\
\hline \multicolumn{8}{|l|}{ Vova'u } \\
\hline No code & Vuna, Pangaimotu Island & coastal dune & 1500 & full range & Late & $2850-2750$ & $\begin{array}{l}\text { Burley this volume; Burley and } \\
\text { Connaughton } 2007\end{array}$ \\
\hline No code & Ofu Island & coastal dune & 1500 & full range & Late & $2900-2750$ & $\begin{array}{l}\text { Burley this volume; Burley and } \\
\text { Connaughton } 2007\end{array}$ \\
\hline No code & ‘Otea, Kapa Island & coastal dune & 800 & full range & Late & $2850-2750$ & $\begin{array}{l}\text { Burley this volume; Burley and } \\
\text { Connaughton } 2007\end{array}$ \\
\hline No code & Falevai, Kapa Island & coastal dune & 600 & full range & Late & $2850-2750$ & $\begin{array}{l}\text { Burley this volume; Burley and } \\
\text { Connaughton } 2007\end{array}$ \\
\hline No code & Mafana Island & coastal flat & 400 & pottery & Late & - & Burley this volume \\
\hline
\end{tabular}

\section{Acknowledgements}

Matthew Spriggs read an earlier draft of the paper and provided useful comment.

\section{References}

Allen, J. 1984. In search of the Lapita Homeland. Journal of Pacific History 19:186-201.

Allen, J and C. Gosden (eds.) 1991. Report of the Lapita Homeland Project. Occasional Papers in Prehistory 20. Canberra,

Department of Prehistory, Research School of Pacific Studies, Australian National University.

Ambrose, W. 1999. Curves, tines, scutes and Lapita ware. In J-C Galipaud and I. Lilley (eds), The Western Pacific 50002000 BP: Colonisations and transformations, pp. 119-126. Paris: IRD Éditions.

Anderson, A., S. Bedford, G. Clark, I. Lilley, C. Sand, G. Summerhayes and R. Torrence. 2001. An Inventory of Lapita Sites containing dentate-stamped pottery. In G. Clark, A. Anderson and T. Sorovi-Vunidilo (eds), The Archaeology of Lapita Dispersal in Oceania: Papers from the Fourth Lapita Conference, June 2000, Canberra, Australia, pp. 1-14. Canberra: Centre for Archaeological Research and Department of Archaeology and Natural History, Australian National University. Terra Australis 17.

Anderson, A. and G. Clark 1999. The Age of Lapita Settlement in Fiji. Archaeology in Oceania 34:31-39.

Anson, D. 1983. Lapita Pottery of the Bismarck Archipelago and its Affinities. Unpublished PhD thesis. University of Sydney, Australia.

Anson, D., R. Walter and R.C. Green 2005. A revised and redated event phase sequence for the Reber-Rakival Lapita site, Watom Island, East New Britain Province, Papua New Guinea. Dunedin: University of Otago Studies in Prehistoric Anthropology 20.

Barp, F., D. Baret, S. Domergue and M-K. Haluathr 2006. Projet Koniambo. Etude archéologique phase 3. Rapport Final d'Opération. Nouméa : Rapport interne Falconbridge. 
Bedford, S. 2003. The timing and nature of Lapita colonisation in Vanuatu: the haze begins to clear. In C. Sand (ed), Pacific Archaeology: assessments and prospects, pp. 147-158. Nouméa: Les Cahiers de l'archéologie en Nouvelle-Calédonie 15.

Bedford, S. 2006a. Pieces of the Vanuatu Puzzle: Archaeology of the North, South and Centre. Canberra: Pandanus Press, Australian National University. Terra Australis 23.

Bedford, S. 2006b. The Pacific's earliest painted pottery: an added layer of intrigue to the Lapita debate and beyond. Antiquity 80:544-557.

Bedford, S. and G. Clark 2001. The Rise and Rise of the Incised and Applied Relief Tradition: a review and reassessment. In G. Clark, A. Anderson and T. Sorovi-Vunidilo (eds), The Archaeology of Lapita Dispersal in Oceania: Papers from the Fourth Lapita Conference, June 2000, Canberra, Australia, pp. 61-74. Canberra: Centre for Archaeological Research and Department of Archaeology and Natural History, Australian National University. Terra Australis 17.

Bedford, S and M. Spriggs 2007. Northern Vanuatu as a Pacific Crossroads: the Archaeology of Discovery, Interaction and the Emergence of the 'Ethnographic present'. Asian Perspectives.

Bedford, S., A. Hoffman, M. Kaltal, R. Regenvanu and R. Shing. 2004. Dentate-stamped Lapita reappears on Efate, Central Vanuatu: A four decade long drought is broken. Archaeology in New Zealand 47:39-49.

Bedford, S., M. Spriggs and R. Regenvanu 2006. The Teouma Lapita site and the early human settlement of the Pacific Islands. Antiquity 80:812-828.

Bellwood, P. 1978. Man's Conquest of the Pacific. London: Collins.

Best, S. 2002. Lapita: A View from the East. Auckland: New Zealand Archaeological Association Monograph No. 24. Burley, D., 1998. Tongan archaeology and the Tongan Past, 2850-150 BP. Journal of World Prehistory 12:337-392.

Burley, D. and S. Connaughton 2007. First Lapita settlement and its chronology in Vava'u, Kingdom of Tonga. Radiocarbon 49:131-137.

Burley, D. and W. Dickinson 2001. Origin and significance of a founding settlement in Polynesia. Proceedings of the National Academy of Sciences 98(20):11829-11831.

Burley, D., D. E. Nelson and R. Shutler Jr. 1999. A radiocarbon chronology for the Eastern Lapita frontier in Tonga. Archaeology in Oceania 34:59-70.

Burley, D., A. Storey and J. Witt 2002. On the Definition and Implications of Eastern Lapita Ceramics in Tonga. In S. Bedford, C. Sand and D. Burley (eds), Fifty Years in the Field: Essays in Honour and celebration of the archaeological career of Richard Shutler Jr, pp. 213-226. Auckland: New Zealand Archaeological Association Monograph No.25.

Chiu, S. 2005. Meanings of a Lapita Face: Materialized Social Memory in Ancient House Societies. Taiwan Journal of Anthropology 3:1-47.

Clark, G., A. Anderson and T. Sorovi-Vunidilo (eds) 2001. The Archaeology of Lapita Dispersal in Oceania: Papers from the Fourth Lapita Conference, June 2000, Canberra, Australia. Terra Australis 17. Canberra: Centre for Archaeological Research and Department of Archaeology and Natural History, Australian National University.

Clark, G. and T. Murray 2006. Decay characteristics of the eastern Lapita design system. Archaeology in Oceania 41:107-117.

Dickinson, W. 2006. Temper Sands in Prehistoric Oceanian Pottery: Geotectonics, Sedimentology, Petrography, Provenance. Colorado: The Geological Society of America. Special Paper 406.

Felgate, M. 2001. A Roviana ceramic sequence and the prehistory of Near Oceania. In Clark, G., A. Anderson and T. Sorovi-Vunidilo (eds), The Archaeology of Lapita Dispersal in Oceania: Papers from the Fourth Lapita Conference, June 2000, Canberra, Australia, pp. 39-60. Terra Australis 17. Canberra: Centre for Archaeological Research and Department of Archaeology and Natural History, Australian National University.

Galipaud, J-C. 2001. Survey of Prehistoric Sites in Aore. Preliminary assessment. Unpublished report to Vanuatu Cultural Centre. 
Galipaud, J-C. and B. Vienne 2005. Chronologie du peuplement et réseaux d'échanges dans le nord du Vanuatu. Mission Santo 2005. Rapport préliminaire. Nouméa: IRD.

Garling, S. 2003. Tanga Takes to the Stage: Another model 'Transitional Site'? New Evidence and a contribution to the 'Incised and Applied Relief Tradition' in New Ireland. In C. Sand (ed.), Pacific Archaeology: assessments and prospects, pp. 213-233. Nouméa: Les Cahiers de l'archéologie en Nouvelle-Calédonie 15.

Gifford and R. J. Shutler Jr. 1956. Archaeological Excavations in New Caledonia. Anthropological Records 18 (1). Berkeley and Los Angeles; University of California Press.

Golson, J. 1971. Lapita ware and its transformations. In R. Green and M. Kelly (eds.) Studies in Oceanic Culture History, Vol. 2, pp.67-76. Pacific Anthropological Records No.12. Honolulu: Bishop Museum.

Golson, J. 1977. The Ladder of Social Evolution: archaeology and the bottom rungs. Sydney: Sydney University Press for the Academy of the Humanities.

Gosden, C., J. Allen, W. Ambrose, D. Anson, J. Golson, R. Green, P. Kirch, I. Lilley, J. Specht and M. Spriggs 1989. Lapita sites in the Bismarck Archipelago. Antiquity 63:561-86.

Green, R.C. 1976. Lapita Sites in the Santa Cruz Group. In Green, R.C. and M.M. Cresswell (eds), Southeast Solomon Islands Cultural History. A Preliminary Survey, pp. 245-265. Wellington: The Royal Society of New Zealand, Bulletin 11.

Green, R.C. 1978. New sites with Lapita pottery and their implications for an understanding of the settlement of the Western Pacific. Working Papers in Anthropology, Archaeology and Maori Studies, No. 51. Auckland: Department of Anthropology, University of Auckland.

Green, R.C. 1979. Lapita. In J.D. Jennings (ed.) The Prehistory of Polynesia, pp. 27-60. Cambridge, Mass.: Harvard University Press.

Green, R. C. 1985. Comment: Sprigg's ‘The Lapita Cultural Complex’. The Journal of Pacific History 20:220-224.

Green, R.C. 1991. The Lapita Cultural Complex: Current Evidence and Proposed Models. Bulletin of the Indo-Pacific Prehistory Association 11(2):295-305.

Green, R.C. 2002a. A Retrospective View of Settlement Pattern Studies in Samoa. In T. Ladefoged and M. Graves (eds) Pacific Landscapes Archaeological Approaches, pp. 125-152. The Easter Island Foundation. California: Bearsville Press.

Green, R.C. 2002b. Rediscovering the Social Aspects of Ancestral Oceanic Societies through Archaeology, Linguistics, and Ethnology. In S. Bedford, C. Sand and D. Burley (eds), Fifty Years in the Field. Essays in Honour and Celebration of Richard Shutler Jr's Archaeological Career, pp. 21-36. Auckland: NZ Archaeological Association Monograph 25.

Green, R.C. 2003. The Lapita horizon and traditions - Signature for one set of oceanic migrations. In C. Sand (ed.), Pacific Archaeology: assessments and prospects (Proceedings of the Conference for the 50th anniversary of the first Lapita excavation. Koné-Nouméa 2002), pp. 95-120. Nouméa: Les Cahiers de l'archéologie en NouvelleCalédonie 15.

Green, R. C. and P. V. Kirch 1997. Lapita exchange systems and their Polynesian transformations: seeking explanatory models. In M. Weisler (ed.), Prehistoric long-distance interaction in Oceania: an interdisciplinary approach, pp. 19-37. Auckland: New Zealand Archaeological Association Monograph 21.

Horrocks, M, and S. Bedford 2005. Microfossil analysis of Lapita deposits in Vanuatu reveals introduced Araceae (aroids). Archaeology in Oceania 39:67-74.

Jones, M., F. Petchey, R.C. Green, P. Sheppard and M. Phelan 2007. The Marine $\Delta$ R for Nenumbo (Solomon Islands): A case study in calculating reservoir offsets from paired sample data. Radiocarbon 49:95-102.

Kirch, P.V. 1987. Lapita and Oceanic cultural origins: Excavations in the Mussau Islands, Bismarck Archipelago, 1985. Journal of Field Archaeology 14:163-180. 
Kirch, P.V. 1988. Problems and Issues in Lapita Archaeology. In P.V. Kirch and T. Hunt (eds), Archaeology of the Lapita Cultural Complex: A Critical Review, pp. 158-165. Seattle: Thomas Burke Memorial Washington State Museum Research Report No.5.

Kirch, P.V. 1990. Specialization and exchange in the Lapita complex of Oceania (1600-500 B.C.). Asian Perspectives 29:117-133.

Kirch, P.V. 1997. The Lapita Peoples. Ancestors of the Oceanic World. Oxford: Blackwell.

Kirch, P.V. (ed.) 2001. Lapita and its Transformations in Near Oceania. Contribution No. 59, Archaeological Research Facility. Berkeley: University of California.

Kirch, P.V. and T. Hunt 1988. The Spatial and Temporal Boundaries of Lapita. In P.V. Kirch and T. Hunt (eds.), Archaeology of the Lapita Cultural Complex: A Critical Review, pp. 9-32. Thomas Burke Memorial Washington State Museum Research Report No.5. Seattle: The Burke Museum.

Kumar, R. 2002. Discovery of a Lapita sherd inland of the northeast coast of Viti Levu Island, Fiji: insights and implications. The University of the South Pacific, Institute of Applied Sciences Technical Report 2002/6.

Kumar, R., P.D. Nunn and W.R. Dickinson 2004. The emerging pattern of earliest human settlement in Fiji: four new Lapita sites on Viti Levu Island. Archaeology in New Zealand 47:108-117.

Lilley, I. 2002. Lapita and Type Y pottery in the KLK site, Siassi, Papua New Guinea. In S. Bedford, C. Sand and D. Burley (eds), Fifty Years in the Field. Essays in Honour and Celebration of Richard Shutler Jr's Archaeological Career, pp. 79-90. Auckland: New Zealand Archaeological Association Monograph 25.

Nunn, P.D., R. Kumar, S. Matararaba, T. Ishimura, J. Seeto, S. Rayawa, S. Kuruyawa, A. Nasila, B. Oloni, A. Rati Ram, P. Saunivalu, P. Singh and E. Tegu 2004. Early Lapita settlement site at Bourewa, southwest Viti Levu Island, Fiji. Archaeology in Oceania 39:139-143.

Nunn, P.D., T. Ishimura, W. Dickinson, K. Katayama, F. Thomas, R. Kumar, S. Matararaba, J. Davidson and T. Worthy 2007. The Lapita occupation of Naitabala, Moturiki Island, Central Fiji. Asian Perspectives 46:96-132.

Nunn, P.D., S. Matararaba, T. Ishimura, R. Kumar and E. Nakoro 2005. Reconstructing the Lapita-era geography of northern Fiji: a newly-discovered Lapita site on Yadua Island and its implications. New Zealand Journal of Archaeology 26 (2004):41-55.

Nunn, P.D., S. Matararaba, R. Kumar, C. Pene, L. Yuen and M.R. Pastorizo 2006. Lapita on an island in the mangroves? The earliest human occupation at Qoqo Island, southwest Viti Levu, Fiji. Archaeology in New Zealand 49:205-212.

O’Day, S.J., P. O’Day and D. Steadman 2004. Defining the Lau Context: Recent findings on Nayau, Lau Islands, Fiji. New Zealand Journal of Archaeology 25 (2003): 31-56.

Pearson, G.W. 1993. High Precision Bidecadal Calibration of the radiocarbon time scale 500-2500 BC. Radiocarbon 35:25-33.

Sand, C. 1999. Lapita and non-Lapita ware during New Caledonia's first millennium of Austronesian settlement. In J-C Galipaud and I. Lilley (eds), The Western Pacific from 5000 to 2000 BP. Colonisation and transformations, pp. 139-159. Paris: IRD Éditions.

Sand, C. 2000. The specificities of the 'Southern Lapita Province': the New Caledonian case. Archaeology in Oceania 35:20-33.

Sand, C. 2001. Evolutions in the Lapita Cultural Complex: a view from the Southern Lapita Province. Archaeology in Oceania 36:65-76.

Sand, C. (ed.) 2003. Pacific Archaeology: assessments and prospects (Proceedings of the Conference for the 50th anniversary of the first Lapita excavation. Koné-Nouméa 2002). Nouméa: Les Cahiers de l'archéologie en NouvelleCalédonie 15.

Sand, C. 2006. Le Lapita Calédonien. Archéologie d'un premier peuplement insulaire océanien. Unpublished "Habilitation à diriger les recherches", EHESS Paris. 
Sand, C. 2007. "Strings of Pearls" and Provinces: modelling the divergent ceramic chronologies of the Western Pacific during the Lapita period. Presentation at the "Lapita antecedents and successors" Conference, Honiara, Solomon Islands, July 2007.

Sand, C., K. Coote, J. Bole and A. Ouetcho 1998. A pottery pit at locality WKO013A, Lapita (New Caledonia). Archaeology in Oceania 33:37-43.

Sand, C., Y-C. Liu and S. Chiu 2007. What next? Pressing archaeological questions in Austronesian studies in Island Southeast Asia. In S. Chiu and C. Sand (eds), From Southeast Asia to the Pacific. Archaeological Perspectives on the Austronesian Expansion and the Lapita Cultural Complex, pp. 269-291. Taipei: Center for Archaeological Studies. Research Center for Humanities and Social Sciences, Academia Sinica.

Sheppard, P. and R.C. Green 1991. Spatial analysis of the Nenumbo (SE-RF-2) Lapita site, Solomon Islands. Archaeology in Oceania 26:89-101.

Sheppard, P. and R. Walter 2006. A Revised Model of Solomon Islands Culture History. Journal of the Polynesian Society 115(1):47-76.

Shutler, R. Jr. and J. Marck 1975. On the dispersal of the Austronesian Horticulturalists. Archaeology and Physical Anthropology in Oceania 13 (2\&3):215-28.

Shutler, R. Jr. and M.E. Shutler 1975. Oceanic Prehistory. California: Cummings Publishing.

Specht, J. 1968. Preliminary Report of Excavations on Watom Island. Journal of the Polynesian Society 77(2): 117-34.

Specht, J. 2007. Lapita antecedents: the Bismarck Archipelago as homeland or transit lounge? Presentation at the "Lapita antecedents and successors" Conference, Honiara, Solomon Islands, July 2007.

Specht, J. and R. Torrence in press. Pottery of the Talasea area, West New Britain Province, Papua New Guinea. Technical Reports of the Australian Museum.

Spriggs, M. 1984. The Lapita Cultural Complex: origins, distribution, contemporaries and successors. Journal of Pacific History 19 (4):202-23.

Spriggs, M. (ed.) 1990a. Lapita design, form and composition: proceedings of the Lapita design workshop, Canberra, Australia, December 1988. Occasional Papers in Prehistory 18. Canberra: Department of Prehistory, Australian National University.

Spriggs, M.J.T. 1990b. Dating Lapita: Another View. In M.J.T. Spriggs (ed.), Lapita design, form and composition: proceedings of the Lapita design workshop, Canberra, Australia, December 1988, pp.6-27. Occasional Papers in Prehistory 18. Canberra: Department of Prehistory, Research School of Pacific and Asian Studies, Australian National University.

Spriggs, M.J.T. 1996. Chronology and colonisation in Island Southeast Asia and the Pacific: New data and an evaluation. In J. Davidson, G. Irwin, F. Leach, A Pawley and D. Brown (eds.), Oceanic Culture History. Essays in Honour of Roger Green, pp. 33-50. New Zealand Journal of Archaeology Special Publication.

Spriggs, M. 1999. Archaeological dates and linguistic sub-groups in the settlement of the Island Southeast AsianPacific Region. In P. Bellwood, D. Bowdery, D. Bulbeck, M. Kiskesjo, R. Green, I. Lilley and B. Maloney (eds), Indo-Pacific Prehistory: The Melaka Papers, pp. 17-24. Bulletin of the Indo-Pacific Prehistory Association 18. Canberra: Australian National University.

Spriggs, M. 2007. The Neolithic and Austronesian expansion within Island Southeast Asia and into the Pacific. In S. Chiu and C. Sand (eds), From Southeast Asia to the Pacific. Archaeological Perspectives on the Austronesian Expansion and the Lapita Cultural Complex, pp. 104-140. Taipei: Center for Archaeological Studies. Research Center for Humanities and Social Sciences, Academia Sinica.

Spriggs, M. and A. Anderson 1993. Late Colonisation of East Polynesia. Antiquity 67: 200-17.

Summerhayes, G. 2000. Lapita Interaction. Terra Australis 15. Canberra: Department of Archaeology and Natural History and the Centre for Archaeological Research, Australian National University.

Summerhayes, G. 2001. Far Western, Western and Eastern Lapita: A re-evaluation. Asian Perspectives 39:109-138. 
Summerhayes, G., L. Matisoo-Smith, J.Specht and H. Mandui 2007. Observations of a Lapita site on Emira. Presentation at the "Lapita antecedents and successors" Conference, Honiara, Solomon Islands, July 2007.

Summerhayes, G. and I. Scales 2005. New Lapita Pottery Finds from Kolombangara, Western Solomon Islands. Archaeology in Oceania 40:14-20.

Swadling, P., B. Hauser Schäublin, P. Gorecki and F. Tiesler 1988. The Sepik-Ramu: an introduction. Boroko: A PNG National Museum Publication.

Terrell, J. and R. Welsch 1997. Lapita and the temporal geography of prehistory. Antiquity 71:548-572.

Torrence, R. 2007. Holocene interaction spheres: implications of Melanesian antecedents to Lapita. Presentation at the "Lapita antecedents and successors" Conference, Honiara, Solomon Islands, July 2007.

Torrence, R. and C. Stevenson 2000. Beyond the beach: changing Lapita landscapes on Garua Island, Papua New Guinea. In A. Anderson and T. Murray (eds), Australian Archaeologist. Collected Papers in honour of Jim Allen, pp. 324-347. Centre for Archaeological Research and Department of Archaeology and Natural History. Canberra: Australian National University.

Torrence R. and J.P. White. 2001. Tattooed faces from Boduna Island, Papua New Guinea. In G.A. Clark, A. Anderson and T. Sorovi-Vunidilo (eds.) The Archaeology of Lapita Dispersal in Oceania: Papers from the Fourth Lapita Conference, June 2000, Canberra, Australia, pp. 135-140. Terra Australis 17. Canberra: Centre for Archaeological Research and Department of Archaeology and Natural History, Australian National University.

Tsang, C.H. 2007. Recent archaeological discoveries in Taiwan and Northern Luzon. Implications for Austronesian expansion. In S. Chiu and C. Sand (eds), From Southeast Asia to the Pacific. Archaeological perspectives on the Austronesian Expansion and the Lapita Cultural Complex, pp. 47-74. Taipei: Centre for Archaeological Studies.

White, J.P. and J. Allen 1980. Melanesian Prehistory: Some recent advances. Science 207:728-734.

White, J.P., J. Allen and J. Specht 1988. Peopling the Pacific: the Lapita Homeland Project. Australian Natural History 22:410-416. 